\title{
HISTORIA ŚWIADECTWEM CZASÓW. JUBILEUSZ KS. PROF. DR. HAB. MARKA T. ZAHAJKIEWICZA
}

W dniu 29 września 2006 roku odbyła się w Auli Instytutu Muzykologii Wydziału Teologii Katolickiego Uniwersytetu Lubelskiego Jana Pawła II podniosła uroczystość wręczenia księgi pamiątkowej i medalu Wydziału Teologii prof. Markowi T. Zahajkiewiczowi. Na tę szczególną chwilę przybyli uczniowie, wychowankowie, przyjaciele i współpracownicy dostojnego Jubilata.

Spotkanie rozpoczął ks. prof. J. Walkusz, dyrektor Instytutu Historii Kościoła KUL. W krótkim przemówieniu powitał gości, którzy przybyli na jubileusz: abpa prof. Józefa Życińskiego, Wielkiego Kanclerza KUL, ks. prof. M. Stanisława Wilka, Rektora KUL, prof. Józef Ferta, Prorektora KUL, o. prof. Andrzeja Derdziuka OFMCap., ks. prof. Marka Chmielewskiego, ks. prof. Jerzego Pałuckiego, ks. prof. Stanisława Janeczka, rodzinę Jubilata oraz wszystkich gości. W krótkich słowach ks. prof. J. Walkusz wyraził wdzięczność za wieloletnią współpracę z ks. prof. Zahajkiewiczem w Instytucie Historii Kościoła i za wszystko dobro, które było udziałem Jubilata.

Ks. dr Stanisław Tylus, adiunkt w Katedrze Historii Kościoła w Średniowieczu i uczeń Księdza Profesora, przedstawił bogaty życiorys kapłański i naukowy Jubilata. Ks. prof. Marek T. Zahajkiewicz urodził się 18 lutego 1934 roku w Borysławiu, w województwie lwowskim. Naukę w szkole podstawowej rozpoczął w czasie okupacji w Stryju. Po przymusowym opuszczeniu rodzinnych stron, kontynuował edukację w Chełmie. Tam ukończył szkołę podstawową i Liceum Ogólnokształcące im. Stefana Czarnieckiego, uwieńczone egzaminem maturalnym w 1951 roku. Tego samego roku wstąpił do lubelskiego Seminarium Duchownego, stając się równocześnie studentem Katolickiego Uniwersytetu Lubelskiego. W czasie studiów uczęszczał na seminarium naukowe z historii Kościoła, prowadzone przez ks. prof. Mieczysława Żywczyńskiego. Święcenia kapłańskie otrzymał w 1956 roku. Wtedy też został skierowany przez biskupa Piotra Kałwę na specjalistyczne studia $z$ historii Kościoła w KUL. Równolegle do studiowania ks. Zahajkiewicz podjął pracę nauczyciela katechety w szkole podstawowej nr 9 w Lublinie. W latach 1957-1959 musiał przerwać edukację na KUL, w związku 
z koniecznością podjęcia pracy duszpasterskiej w Krasnymstawie na stanowisku wikariusza oraz nauczyciela religii w szkołach. Po powrocie do Lublina ukończył w 1961 roku studia uniwersyteckie, pisząc pod kierunkiem ks. prof. Mariana Rechowicza pracę magisterską Liturgia mszy świetej w świetle «Tractatus sacerdotalis» Mikołaja z Błonia. Po ukończeniu studiów został wikariuszem parafii św. Pawła w Lublinie. W 1965 roku został jednak zwolniony z pracy duszpasterskiej i zatrudniony na stanowisku asystenta w Katedrze Historii Liturgii na Wydziale Teologii KUL. Po otrzymaniu doktoratu w 1967 roku na podstawie pracy Msza Święta w Polsce do Soboru Trydenckiego w świetle rodzimych komentarzy, został przeniesiony na stanowisko asystenta w Katedrze Historii Kościoła w Sredniowieczu. Od sierpnia 1972 do lutego 1973 roku przebywał na stypendium naukowym za granicą. W tym czasie odwiedził ośrodki naukowe Belgii, Francji, Włoch i Austrii. W czasie swego pobytu skoncentrował się na kwerendzie archiwalnej dotyczącej średniowiecznej reformy Kościoła i popularności nauki polskiej w Europie zachodniej w końcu średniowiecza. W 1973 roku ks. M. Zahajkiewicz otrzymał nominację na stanowisko adiunkta. Owocem jego badań naukowych podczas stypendium zagranicznego była rozprawa «Tractatus sacerdotalis» Mikołaja z Błonia na tle teologii przełomu wieku XIV i XV oraz liczne artykuły. W wyniku kolokwium habilitacyjnego w dniu 4 września 1976 roku Rada Wydziału Teologii KUL nadała mu stopień doktora habilitowanego teologii w zakresie historii Kościoła.

Ks. Marek T. Zahajkiewicz oprócz działalności dydaktycznej pełnił ważne funkcje administracyjne. Był kierownikiem Katedry Historii Kościoła w Średniowieczu w latach 1978-2006. W okresie 1983-2004 kierował Instytutem Historii Kościoła na Wydziale Teologii KUL. Od 1985 do 2006 roku był dyrektorem Ośrodka Archiwów Bibliotek i Muzeów Kościelnych. W tym czasie razem z odbywanymi sympozjami naukowymi, zorganizował szkolenie specjalistów z zakresu trzech podstawowych zbiorów: archiwów, bibliotek i muzeów kościelnych. Nadto był w latach 1987-2006 członkiem Komisji Episkopatu Polski do Spraw Sztuki Kościelnej. Brał również udział w kilku redakcjach czasopism: Biuletynu Informacyjnego KUL, Roczników Teologiczno-Kanonicznych KUL, Archiwów, Bibliotek i Muzeów Kościelnych.

Pod kierunkiem ks. prof. Zahajkiewicza napisano dotąd 149 prac magisterskich i trzy licencjackie. Wypromował również 7 doktorów historii średniowiecznej.

Ks. prof. Marek Zahajkiewicz jest członkiem licznych towarzystw naukowych: Towarzystwa Naukowego KUL, Lubelskiego Towarzystwa Naukowego, Polskiego Towarzystwa Teologicznego oraz Komisji XI Historycznej Oddziału PAN w Lublinie.

Bardzo ważnym rozdziałem w życiu ks. prof. jest jego działalność w fundacji hr. A. Potulickiej. W okresie zmian ustrojowych w Polsce ks. prof. Zahajkiewicz został mianowany pełnomocnikiem Rektora i Senatu KUL do spraw odzyskania zawłaszczonego przez władze komunistyczne mienia KUL. Powierzone mu zadanie ks. Zahajkiewicz wykonał z dużą skutecznością oraz z wielkim zrozumieniem 
wszelkich problemów związanych z restytucją dóbr. Dzięki jego ofiarnej pracy, Uniwersytet odzyskał znaczną część zagrabionych nieruchomości.

Ks. prof. był za swoją ofiarną pracę wielokrotnie nagradzany. W 1979 roku otrzymał nagrodę Rektora KUL za książkę Tractatus sacerdotalis Mikołaja z Błonia na tle teologii przełomu wieku XIV i XV, Lublin 1979. W 1996 roku Rektor KUL przyznał mu nagrodę za „Ofiarną pracę społeczną dla Katolickiego Uniwersytetu Lubelskiego". Również studenci Jubilata wyróżnili go zaszczytnym mianem Pedagoga Roku 2003 na Wydziale Teologii KUL.

Także diecezja lubelska uhonorowała ks. prof. Zahajkiewicza za jego pracę. W 1985 roku został odznaczony godnością kanonika honorowego Kapituły Katedralnej w Lublinie, w 1993 roku godnością kanonika gremialnego Kolegiaty Chełmskiej a od 1999 roku był kapelanem Ojca Świętego. Także władze państwowe nagradzały ks. prof. Zahajkiewicza. Prezydent RP Lech Wałęsa odznaczył go Złotym Krzyżem Zasługi a w 2002 otrzymał Krzyż Kawalerski Orderu Odrodzenia Polski. Nadano mu również Medal Komisji Edukacji Narodowej.

Głównym polem zainteresowań ks. prof. Zahajkiewicza są dzieje Kościoła w średniowieczu. Problematykę tę poruszał w kolejnych swych pracach naukowych. Jednak nie tylko wieki średnie były w centrum badań ks. profesora. Zajął się również przeszłością diecezji lubelskiej. Owocem jego badań były prace: Diecezja lubelska. Informator historyczny i administracyjny, Lublin 1985 oraz Archidiecezja Lubelska. Historia i administracja, Lublin 2000. Do dziś te publikacje są jedynym i niezastąpionym kompendium wiedzy o (archi)diecezji lubelskiej.

W swym przemówieniu ks. Tylus zwrócił uwagę na zasługi ks. prof. Zahajkiewicza. Jego dokonania naukowe stawiają go w jednym rzędzie z profesorami: W. Banaszakiem, B. Kumorem, M. Żywczyńskim czy Rektorem KUL M. Rechowiczem. Ważną cechą Jubilata jest jego duży szacunek dla studenta. To uczniowie za jego pracę dydaktyczną uhonorowali go zaszczytnym mianem Pedagoga Roku. Ks. prof. Zahajkiewicz zawsze był wierny Kresom Wschodnim, gdzie się urodził i skąd przymusowo musiał wyjechać. Zawsze interesował się historią tamtych terenów i zaszczepiał swoim studentom miłość do kresów m.in. przez wycieczki naukowe, które organizował.

Rektor KUL ks. prof. Stanisław Wilk, wręczając księgę pamiątkową ks. prof. Zahajkiewiczowi przypomniał, czym ,promieniował” profesor. Zwrócił uwagę na jego ofiarną, bezinteresowną pracę na rzecz Uniwersytetu, m.in. podczas przewodniczenia Komisji Stypendialnej czy też w odzyskiwaniu zagrabionych nieruchomości KUL. Według Rektora, tak jak Lwów był zawsze wierny Polsce, tak ks. prof. Zahajkiewicz był zawsze wierny Katolickiemu Uniwersytetowi Lubelskiemu.

Księga pamiątkowa pt. Historia świadectwem czasów, którą otrzymał Jubilat powstała pod redakcją ks. dra Włodzimierza Bielaka i ks. dra Stanisława Tylusa. Została ona przygotowana przez przyjaciół, kolegów i uczniów dostojnego Jubilata, jako podziękowanie za pracę naukową i w pięćdziesiątą rocznicę święceń kapłańskich. Publikacja zawiera 37 artykułów na 660 stronach oraz 32 strony fotografii. Księgę otwiera list abpa prof. Józefa Życińskiego do ks. prof. Zahajkiewicza. Następne pismo do Jubilata wystosował Dziekan Wydziału Teologii KUL 
ks. prof. Jerzy Pałucki. Artykuły do księgi napisali: ks. S. Tylus, Wokót osoby Jubilata. Życie i działalność naukowo-dydaktyczna ks. prof. dr hab. Marka Tomasza Zahajkiewicza; ks. W. Bielak, Bibliografia publikacji Księdza profesora Marka T. Zahajkiewicza; S. Bober, Krwawe ślady na wołyńskiej ziemi; ks. A. Bruździński, Symbolika herbu papieża Benedykat XVI; Bractwa religijne w siedemnastowiecznym Krakowie. Zarys problematyki; M. Chuchra, S. Marek, Polscy fideidoniści w strukturach terytorialno-personalnych Kościoła kameruńskiego w latach 19731998; M. Dębowska, Kształcenie dziewczat w klasztorze norbertanek w Imbramowicach w XVIII wieku; ks. F. Drączkowski, Duchowy charakter królestwa Bożego w świetle przekazów patrystycznych; ks. J. Dyl, Polonica teologiczne XVI wieku w Bibliotece Metropolitalnego Wyższego Seminarium Duchownego w Lublinie (BSL); B. Flaga, J. Flaga, Działalność bibliotekarska biskupa Józefa Andrzeja Zatuskiego; ks. K. Góźdź, Człowiek w perspektywie Wcielenia; A. Hamryszczak, Praktyki pobożnościowe bractw i organizacji religijnych w Kalwarii Pacławskiej w XIX i XX wieku; ks. S. Janeczek, Czy szkoła jezuicka zaprzepaściła zdobycze humanizmu? Uwagi na marginesie lektur z dziejów kultury polskiej; ks. A. Kaim, Mistrz i przyjaciel. Wojciech Nowopolczyk i humanizm chrześcijański; ks. S. Koczwara, Miłość ojczyzny w ujęciu świętego arcybiskupa Józefa Bilczewskiego, metropolity Lwowa; ks. J. Krętosz, Skarby z Otyni na Pokuciu i ich ewakuacja na Ślask po zakończeniu II wojny światowej; ks. J. Marczewski, $Z$ dziejów bernardynów lubelskich $w$ dobie potrydenckiej. In Coena Domini 1699; ks. T. Moskal, Wizytacja parafii Sulisławie w 1782 roku; B. Noworyta-Kuklińska, Ottarz-miejsce ofiary i prezentacji idei ikonograficznych; ks. J. Pałucki, Spes autem non confundit in aeternum; $\mathrm{o}$. R. Prejs, Galicyjskie drogi franciszkańskich zakonników zesłańcówpopowstaniustyczniowym; ks. M. Rusecki, Wktadchrześcijaństwawedukacje; B. Skrzydlewska, O integralna wizje muzeum w kulturze; R. Skrzyniarz, Średniowieczne kaznodziejstwo zakonne na ziemiach polskich. Zarys problematy$k i$; ks. B. Stanaszek, Ślubowanie księży na wierność PRL w diecezji sandomierskiej w 1953 roku; ks. P. Szczur, List św. Leandra do Florentyny reguła monastyczna?? ks. M. Szram, Herodot i Tukidydes w pismach wczesnochrześcijańskich pisarzy aleksandryjskich; ks. J. Szymański, Kośció katolicki w obwodzie kamieniecko-podolskim w 1945 r.; ks. J. Walkusz, Geneza i powstanie polskiej parafii etnicznej w London, Ontario; ks. A. Weiss, Dokument lokacyjny króla Jana II Sobieskiego dla Obry - Bernardowa; ks. S. Wilk, Apelacja benedyktynek kowieńskich do Stolicy Apostolskiej w 1920 roku; ks. J. Wołczański, Relacje z sowieckich przestuchań świadków napadów ukraińskich nacjonalistów na klasztor OO Dominikanów w Podkamieniu i okoliczne wioski w 1944 roku; ks. S. Zabraniak, Z dziejów szkolnictwa w Wieluniu (do końca XVIII w.); ks. D. Zagórski, Jak posia-

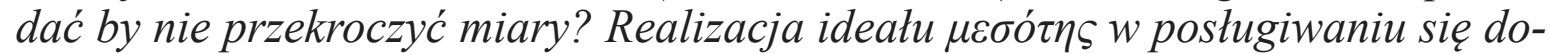
brami materialnymi wedtug Klemensa Aleksandryjskiego; o. P. Zając, Metody katolickiej ewangelizacji Inwit w rejonie Zatoki Hudsona 1912-1942; ks. Z. Zieliński, Mistrzowie w pamięci ucznia; o. H. Zimoń, Etnohistoria rodu królewskiego Abasiranga na wyspie Bukerebe w Tanzanii do połowy XVIII wieku.

Oprócz księgi pamiątkowej ks. prof. Zahajkiewicz otrzymał z rąk Dziekana Wydziału Teologii KUL, „Złoty dyplom” z okazji jubileuszu 50-lecia przyjęcia święceń kapłańskich. Uzasadniając decyzję przyznania dyplomu, ks. Dziekan 
stwierdził, że Jubilat stał się poprzez swą kapłańską działalność mistrzem dla swych braci w kapłaństwie.

Uroczyste spotkanie podsumował Wielki Kanclerz KUL abp prof. Józef Życiński. W swym przemówieniu ukazał wielkie umiłowanie Kościoła oraz pracy naukowej przez ks. prof. Zahajkiewicza. Pokazał również na przykładzie Jubilata etos mistrza, wyrażający się w przyjacielskiej więzi miedzy profesorem a jego uczniami. Kończąc stwierdził, że jest dumny i wdzięczny, iż Kościół lubelski ma takiego kapłana. Ks. prof. Zahajkiewicz kończąc uroczystość podziękował gościom oraz współpracownikom za wszelkie dobro, które od nich otrzymał.

Dziękując ks. prof. Markowi T. Zahajkiewiczowi w imieniu pracowników Instytutu Archiwów, Bibliotek i Muzeów Kościelnych KUL za lata owocnej pracy, życzymy mu wielu łask Bożych na dalsze lata życia i wszelkiej pomyślności.

Ad multos annos! 